\title{
The Temporal Variation of the Change of Green Areas in Baghdad City for the Period (2011-2016)
}

\author{
Dr. Israa Talal Dawood ${ }^{1}$
}

\begin{abstract}
:
The research explained the time sequence of green zones which give a reality of the special situation of these areas and the shrinking extent of their areas for the interest of built areas. The field study of the research revealed two types of spaces: the built space which represents all the spaces of concrete, iron, or asphalt nature penetrating the city environment that exist in the city, and the green space represented by the areas of individual characteristics and need a sustainable care for representing a living organism with requirements that should be provided so that they take their space in the city. The research revealed a decline in the area of green zones which is caused by the annual increase of population size, the increase of demand over the residential supply and also the increase in the size of middle and small industries on the account of green lands. Also, the field study of the research showed that there are two functions controlling the use of green zones, one of them of closed nature that is only used by the concerned one, especially sports stadiums of all kinds and swimming pools, and the other of open nature distributed hierarchically according to the importance of the city and its population size, representing entertainment and recreational areas for all people. As for the per capita share in Baghdad city of green zones in their special and general total, it is $(0.02 \mathrm{~m} 2 /$ people) which is very low when compared to the planning standard associated with hot areas as in the case of Baghdad city, where it should be (12m2/people).

Hypothesis of the Research: The nature of the climatic conditions, the lack of water availability and the weakness of the local authority in its interest in this use resulted in the decline of the green zones in Baghdad city. Aim of the Research: The research aims at shedding the light on the phenomenon of green zones, tracking the years that give reality to the situation of these areas, the shrinking extent of their areas in favor of built-up areas, the poor attention, and the lack of attention to this decline by local authorities. Method of Research: The researcher used the descriptive and analytic method in writing the research. Research Population: The researcher selected the green areas in Baghdad city as the research population and sample. Methods of Data Collection: The researcher relied on the field study and Baghdad Municipality as well the Ministry of Planning in collecting the data. Statistical Methods Used in the Research: Simple statistical methods were used to extract the areas of green zones through the data obtained from Baghdad Municipality and the Ministry of Planning.
\end{abstract}

Keywords: green zones, green areas, Baghdad Municipality, orchards, nurseries, per capita share, and agricultural areas.

\section{Introduction}

The city anciently was interested in residence rather than any other thing and takes positions difficult to reach such as being in the middle of a desert, mountain or terrain area, because the characteristic of continual war and invasion between the areas populations was existent, for the need for having the river water controlled by strong groups was a requirement to rush towards the cities which were considered by the village 
and desert populations luxurious. With the passage of time, the advancement of humanity, man's stability and his practice of agriculture, man had a space of time to think and meditate, thus the civilizations started to dominate as in Iraq, Egypt, India, Sind and Gang valley, North of India, Pakistan, China, Mexico, and South America.

The continuous advance of man and his stability in the place made the cities increase and emerge in an unprecedented way in different places of the world until the cities became a phenomenon, in that they were interested in their various uses and functions to serve their inhabitants. In the renaissance, the cities attained their peak and they also prospered in the Middle East such as Damascus, Baghdad, Jericho as well as the cities of North Africa, making the ones who ruled them more luxurious and more interested in them which resulted in taking care of entertaining and recreational services such as establishing orchards and parks to amuse the inhabitants and add joy to their attendants.

In the $19^{\text {th }}$ century, the cities took a serious reality in being a source of rule, increasing in number and some also emerging as million cities in a phenomenon seen as advanced cities because they polarize population due to their great importance; therefore, the interest in them and the urgent need to allocate areas of land use appeared so as to be green zones and these areas are considered as one of the most important necessities of establishing cities. The criteria related to it concerning the one individual need started to emerge, even we find at present that there is no city without uses allocated within the basic design to open areas, parks, water bodies, and amusement cities as well as green paths spread in various places of the city, because such areas maintain the environment, as well as the psychological side they reflect to the city inhabitants, they also release quantities of oxygen during the day, resulting in the improvement of the climatic state of the city, that is why the research came in this topic which was adopted by the researcher to identify the status of Baghdad city in relation to the distributive aspect of the green zones within the city. The green zones in this research include the open areas, parks, water bodies, and green paths among streets and within the neighborhood and the lane in Baghdad city.

As for the green zones under consideration, the researcher preferred to develop her own definition, which was (the green zones are the open spaces directly with the climatic conditions and are with different areas in terms of planning and positional considerations determined by official directions to serve the society and the individual, and some of them are general by their openness to all and some others are special within the houses. These areas take their hierarchy in terms of the importance of the city and its population size.

\section{Problem of the Research:}

Why do the green zones decline in Baghdad city?

\subsection{First- Classifying the Green Zones inside the City:}

The entire city is an open space that is likely to have many variations that the city needs to be suitable for urban dwellers; therefore, the different spaces are distributed in different parts of the city, and these spaces almost overlap with each other for complementary purposes to the urban environment ${ }^{(i)}$, thus, it is possible to note that there are closed spaces such as in the residential houses and governmental buildings and institutions even if they include in some of their areas open places depending on the 
nature of the building and its need for open spaces that may be empty or green. Accordingly, we can find two types of spaces:

\section{1- The Built Space:}

This space represents everything that exists in the city of facilities of concrete, iron or asphalt character that permeates the city environment. This is of course a necessary space, as it occupies a large area of the city at the expense of other spaces, as studies indicate that the residential areas occupy between (40-60\%) of the city area, and the streets occupy about $(1 / 3)$ of the city area(ii), and the greater the residential space in the city, the lower the areas of other regions, because this means that the size of population is large, which requires the presence of more services to meet its needs ${ }^{(i i i)}$.

\section{2- The Green Space:}

Such spaces are important for the city and its population, because they soften the atmosphere of the city and bring comfort to its inhabitants, and they are areas with individual characteristics and need sustainable attention because they represent a living entity with requirements that must be available so as to take their place from the city(iv). This is determined by criteria that may be local or international to suit the one individual (per capita) share inside the city, making it a viable place to live in. The green zones include everything related to parks, orchards, riverbeds, water bodies and sports fields. As for cemeteries, they are in our Arab cities in general and Iraq in particular and nobody cares to make them green spaces as in the western and advanced cities which are a place with a full green space(v).

\subsection{Second- Functions of Open Green Zones:}

When conducting the field tours within the city of Baghdad based on map (1), the researcher found that there are two functions controlling the use of green zones, one

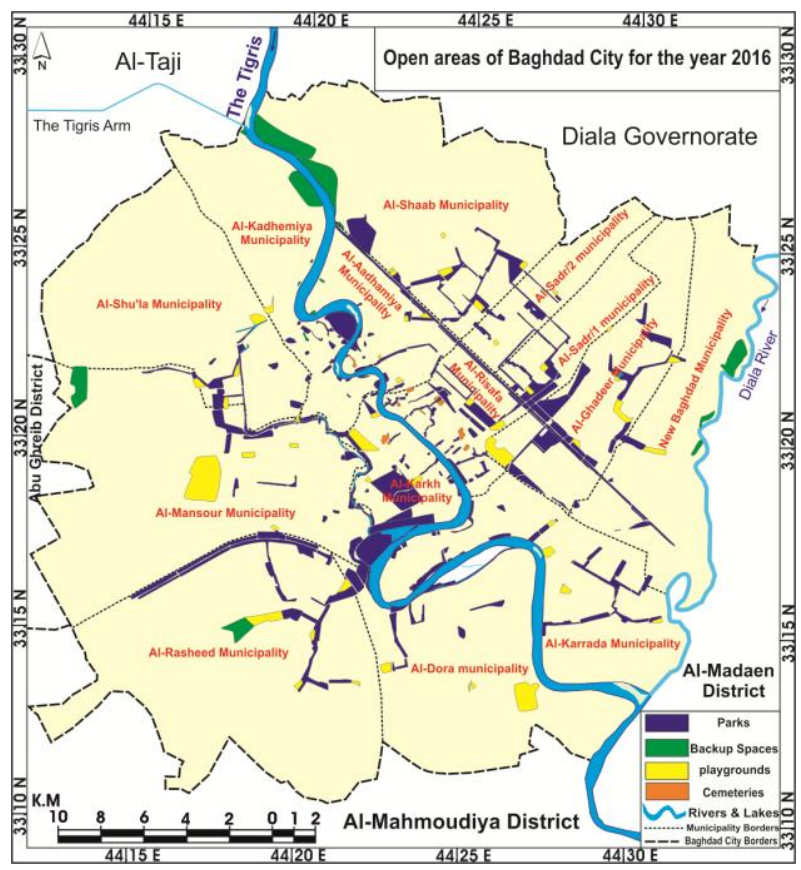
of them is of closed nature, which is used only for those who are related to them especially sports fields with their types and swimming pools, and these are determined by the dimensions imposed by the laws of the game practiced on them.

Map 1.

Source: Baghdad Municipality, Office of Designs- Geographic Information Dept. 
As for open green zones, they are distributed hierarchically according to the importance of the city and its population size and represent recreation areas for the general public such as parks and river courses. Also, such zones appear in residential neighborhoods as well as in some of their lanes*.

\subsection{Third- The Variation of Green Zones in the City of Baghdad:}

The area of Baghdad city is $\left(861 \mathrm{~km}^{2}\right)^{(\mathrm{vi})}$, the green zones occupy an area of about $\left(86.157 \mathrm{~km}^{2}\right)$ of it(vii), i.e. a percentage of $(10 \%)$ of the total area of the city. Such area of green zones in Baghdad city which is populated by nearly (5017501 million people)(viii) means that the one individual share in Baghdad city of green zones in their special and general total is $\left(0.02 \mathrm{~m}^{2} /\right.$ person) which is very low when compared by the schematic standard associated to the areas of hot climate as in Baghdad city, as it should be $\left(12 \mathrm{~m}^{2} / \text { person) }\right)^{(\mathrm{ix})}$.

The variation appears in the distribution of green zones in Fig.(1).

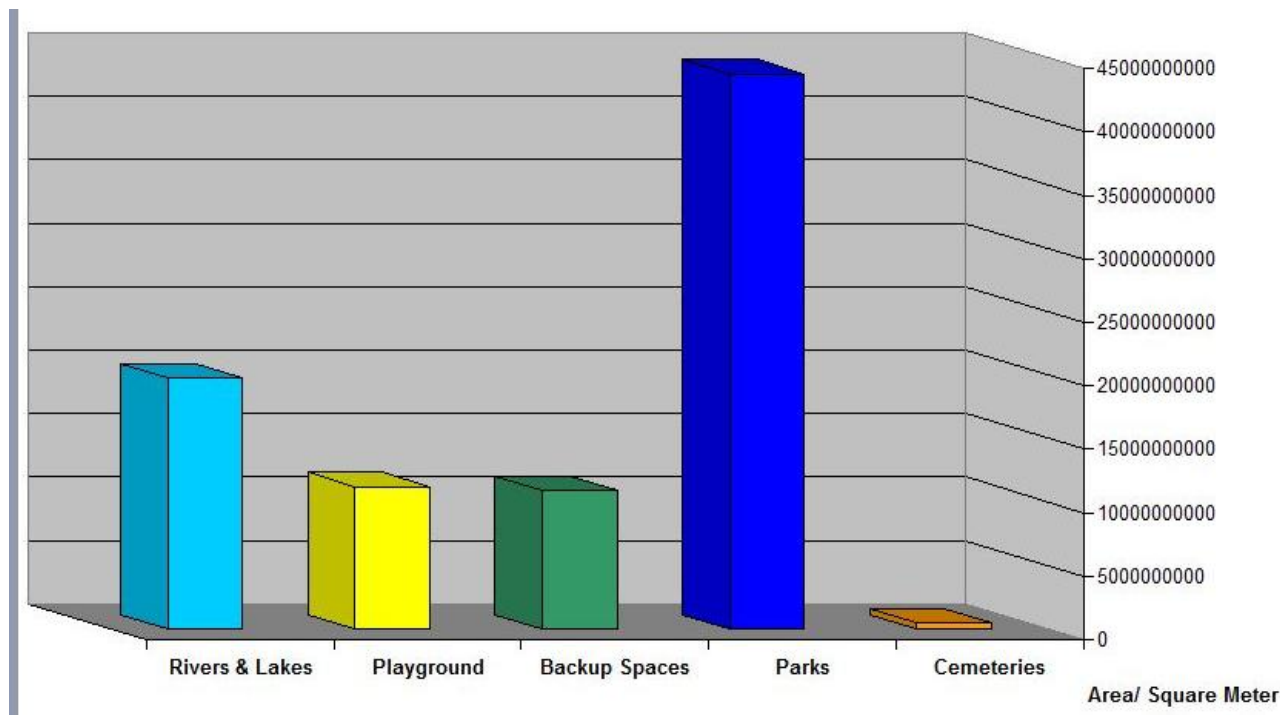

Fig. 1.

Source: Baghdad Municipality, Office of Designs- Preparation of Planning Data section, Urban Planning Dept.

Also, map (1) shows that the distribution of cemeteries is confined to the middle of Baghdad city, especially in Al-Karkh side. For information, Baghdad Municipality does not care to turn them into green zones, so they remained barren land without planting. At the same time, the researcher's observations* show that parks clearly appear at both sides of Qanat Al-Jaish, especially the eastern part of it. As for Al-Karkh side, they are almost at the right side of the Tigris river in front of Al-Jadiriyah area and at both sides of the road leading to Baghdad Airport. They also appear at the extensions of a number of roads inside the city.

As for the areas which are considered as places that can be invested if necessary, they exist in the north of Baghdad city, at its west and at the south of the airport road. Also, 
these areas appear near to Diala river, while the sports fields are distributed at both sides of Baghdad city, as shown in map (1), giving the impression that their distribution meet the needs of residential neighborhoods, each according to his region due to the importance of this use in absorbing the energies of the youth and maintaining their physical and psychological health. Here, the Tigris enters as one of the important open areas for the population of Baghdad city, dividing it into two sides Al-Karkh and AlRisafa, especially that it runs in a region of hot climate; therefore, it has a positive effect in summer*.

Also, the changes of climatic conditions, in which many direct variables by which man builds plants and factories to increase the demand on industrial products contributed, on one hand and the decrease of drinking and irrigation water at the international level on the other hand led to the decline of green areas. As for the indirect variables, they are neglect and non-awareness of population of the importance of these uses inside the city as well as the low budget allocated to sustain them inside the city, which contributed in the evident decline of these areas. Note that in all of the world cities, their local authorities give importance to the green zones parallel to medical, educational and service interests on the grounds that each of these variables is complementary to the other in highlighting the image of the city suitable for living by its inhabitants $(\mathrm{x})$.

\subsection{Fourth- Distributing the Green Zones ${ }^{*}$ on the Municipalities of Baghdad City ${ }^{(\mathrm{xi})}$ for the Year 2011:}

1-Al-Shaab Municipality: In this municipality, eleven residential neighborhoods are distributed with variant population sizes in terms of the neighborhood capacity and its number of houses; therefore, we can note that the total of their population is about (254579 people) for the year (2011), as its percentage to the overall city population is (7.6\%) of the overall Baghdad city population (3345000 people). Note that the area of green zones in this municipality has occupied a value of $\left(192000 \mathrm{~m}^{2}\right)$, which indicates a great decrease in the green zones available in this municipality, as the green zone per one person is about $\left(0.75 \mathrm{~m}^{2}\right)$, which is greatly far from the international standard, indicating that the neighborhoods of this municipality have no chance to enjoy such areas necessary for recreation and relief from man's psychological pressures.

2-Al-Sadr Municipality: This municipality is occupied by four residential neighborhoods with population sizes differ from each other, as well as the number of their residential units, for in general they are of small areas dominated by high population density and most of them are void of domestic orchards in the known meaning. Thus, their population size is around (312.411 thousand persons). This size forms approximately $(9.3 \%)$, note that this ratio does not correspond with the green zones in this municipality which are about $\left(250000 \mathrm{~m}^{2}\right)$, i.e. the green zones represent $\left(0.8 \mathrm{~m}^{2} /\right.$ person $)$, indicating the deprivation of the population of this municipality from the existence of entertaining places which should be there within the neighborhoods of this municipality due to the decrease in the green zone allocated per person by the international standard.

3-New Baghdad Municipality: In this municipality, four residential neighborhoods are distributed, Appendix (1), including a population size of (397531 people) and situated east of Baghdad city, with a population ratio to the overall Baghdad city population of 
(3345000 people) about (4.5\%). Note that the area of the open green zones in this municipality is $\left(180000 \mathrm{~m}^{2}\right)$, indicating a decrease in the ratio of what is allocated per individual in this municipality of green zones to $\left(0.5 \mathrm{~m}^{2} /\right.$ person).

4-Al-Aadhamiya Municipality: In this municipality, seven residential neighborhoods appear, including a population size of (149.763 people), forming a ratio about (4.4\%) of the overall Baghdad city population size. Most of the open regions are situated north this municipality with an area of $\left(850000 \mathrm{~m}^{2}\right)$. When the green zone allocated per individual in this municipality, we find it $\left(5.7 \mathrm{~m}^{2} /\right.$ person), despite its relative height compared to previous residential neighborhoods searched before, yet it is still below the international standard adopted per individual. As for the green zones inside the residential neighborhoods, they are of very small areas represented by locations and sites at the Tigris and some are perpendicular to it.

5-Al-Risafa Municipality: Given that this municipality is considered as one of the ancient regions in Baghdad and is located in the middle of it; therefore, the area of the residential neighborhoods is almost small in that it includes (13) residential neighborhoods differ in their population sizes. Its overall population is (115732 people), forming a ratio to the overall Baghdad city population about (4.3\%). Note that the green zones in it do not appear in a clear way except in its eastern parts, especially in the martyr statue and the surrounding area. As for the other place, it is the nurseries which clearly appear at both side of Palestine Street $\left(105 \mathrm{~m}^{2}\right)$, indicating that the individual's share in this municipality is $\left(0.9 \mathrm{~m}^{2} /\right.$ person), which is not even one. Thus, it is considered very low and does not meet the population needs as it should be, at the time when the general security situation suffers from non-stability which is reflected on the population who need and outlet and a breather to spend time by which they soften and decrease life pressures.

6-Al-Ghadeer Municipality: This municipality is occupied by five residential neighborhoods with population sizes almost approximate to each other except Akad and Al-Mu'tasim neighborhoods, where the overall number of the municipality population is (152071 people) with a ratio to the overall Baghdad city population of around (4.5\%). Note that the area of the green zones of this municipality amounts $\left(76120 \mathrm{~m}^{2}\right)$, accordingly the share of the one individual of it in this municipality amounts $\left(0.5 \mathrm{~m}^{2} /\right.$ person $)$, which also does not meet the standard level allocated to each individual, and here Baghdad municipality should turn its attention to increase the spot of green zones inside the municipality and its neighborhoods, especially Al-Risafa side which is regarded as a privileged residential sector with an area of $\left(349.1 \mathrm{~km}^{2}\right)$. It includes a high population and residential density that reaches $\left(3959\right.$ person $/ \mathrm{km}^{2}$ ).

7-Al-Karrada Municipality: It comprises of eight residential neighborhoods with a population size of (136279 people), occupying a ratio of (4.1\%) of the size of Baghdad city population. The green zones occupy the left sides along the Tigris within this municipality. Also, the parks specially disperse in Al-Za'faraniya region with an area about $\left(811016 \mathrm{~m}^{2}\right)$. Accordingly, what is allocated to each individual of these zones amounts around $\left(6 \mathrm{~m}^{2} /\right.$ person), representing half the standard specified to each individual by Baghdad Municipality. As for the municipalities of Al-Karkh side, they appear in six collections as follows: 
1-Al-Karkh Municipality: This municipality represents the ancient area of Al-Karkh side and is situated at the right bank of the Tigris. In view of its ancientness, its residential neighborhoods are multiple depending on the nature of the small areas of the housing on one hand, and the membership of their streets which were in correspondence with the local environment at that time. Accordingly, there appear eight residential neighborhoods in it, and despite this number, yet the number of their population is small amounting about (47611 people). Al-Karkh municipality is confined to its ancient part, while the Tigris from the east and the street of (14 July) from the west, and in this part the green zones do not appear clearly. As for those situated to the west of 14 July Street, most of the green zones are situated in there with a total area of $\left(1500.000 \mathrm{~m}^{2}\right)$; therefore, the one individual share of green zones in this municipality is $\left(31.5 \mathrm{~m}^{2} /\right.$ person), which is higher than the adopted standard $\left(12 \mathrm{~m}^{2} /\right.$ person), indicating that this municipality in this domain is better than Al-Risafa municipality with which is even in ancientness and opposite to it at the Tigris.

2-Al-Rasheed Municipality: This municipality comprises of ten residential neighborhoods and is situated south Baghdad city, with a large area of $\left(67.88 \mathrm{~km}^{2}\right)$. on this basis, it includes a population size of (433794 people), yet the green zones in this municipality lie adjacent to the Tigris as well as in the middle of the municipality. These zones represent the urban agriculture which provides the population of this municipality and Baghdad city with the daily requirements of horticulture and vegetables each according to its season. As for the open zones and parks, they are very little, which means that their total area of orchards within the populated area is $\left(1426112 \mathrm{~m}^{2}\right)$; therefore, the individual's share of it is $\left(6.2 \mathrm{~m}^{2} /\right.$ person), and this ratio is half the standard specified to the one individual, which is considered better in this aspect compared to the rest of previous municipalities.

3-Al-Dora Municipality: This municipality lies south Baghdad city, bordered from the east and north by the course of the Tigris, while from the west bordered by Al-Rasheed municipality. By this situation, it dominates a good area of green zones in which the parks merge with horticulture. This municipality includes five residential neighborhoods with a population size of (167368 people), at the time when the green zones show, as in map (2), that their distribution is adjacent to the right bank of the Tigris, and also amid this municipality, in that its area is around $\left(5103004 \mathrm{~m}^{2}\right)$, so the ratio specified to the one individual is approximately $\left(30.5 \mathrm{~m}^{2} /\right.$ person), which is more than two times and half the standard ratio specified per capita.

4-Al-Mansour Municipality: This municipality is occupied by twelve residential situated in the middle part of Al-Karkh side, with a population size of (297592 people). In this municipality, we find parks and entertaining places, orchards at its western part, and by that these green zones are mixed with each other forming an area of $\left(1246212 \mathrm{~m}^{2}\right)$; therefore, the per capita in this municipality of green zones is $\left(4.2 \mathrm{~m}^{2} /\right.$ person), which represents $(1 / 3)$ of the standard ratio per capita.

5-Al-Shu'la Municipality: Al-Shu'la municipality is occupied by four residential neighborhoods with a population size of (273107 people) forming a ratio of $(8.21 \%)$ of the overall Baghdad city population, in which orchards appear from its north and west. As for the parks, they are amid the municipality in general though some of them disperse in places adjacent to Al-Kadhemiya municipality, with an area of about $\left(1322171 \mathrm{~m}^{2}\right)$, 
which is regarded within the largest of the populated regions. Thus, the per capita in this municipality of green zones is about $\left(4.8 \mathrm{~m}^{2} /\right.$ person), which is below the standard adopted by Baghdad Municipality. Note that the residential aspect is dominating the municipality general landscape.

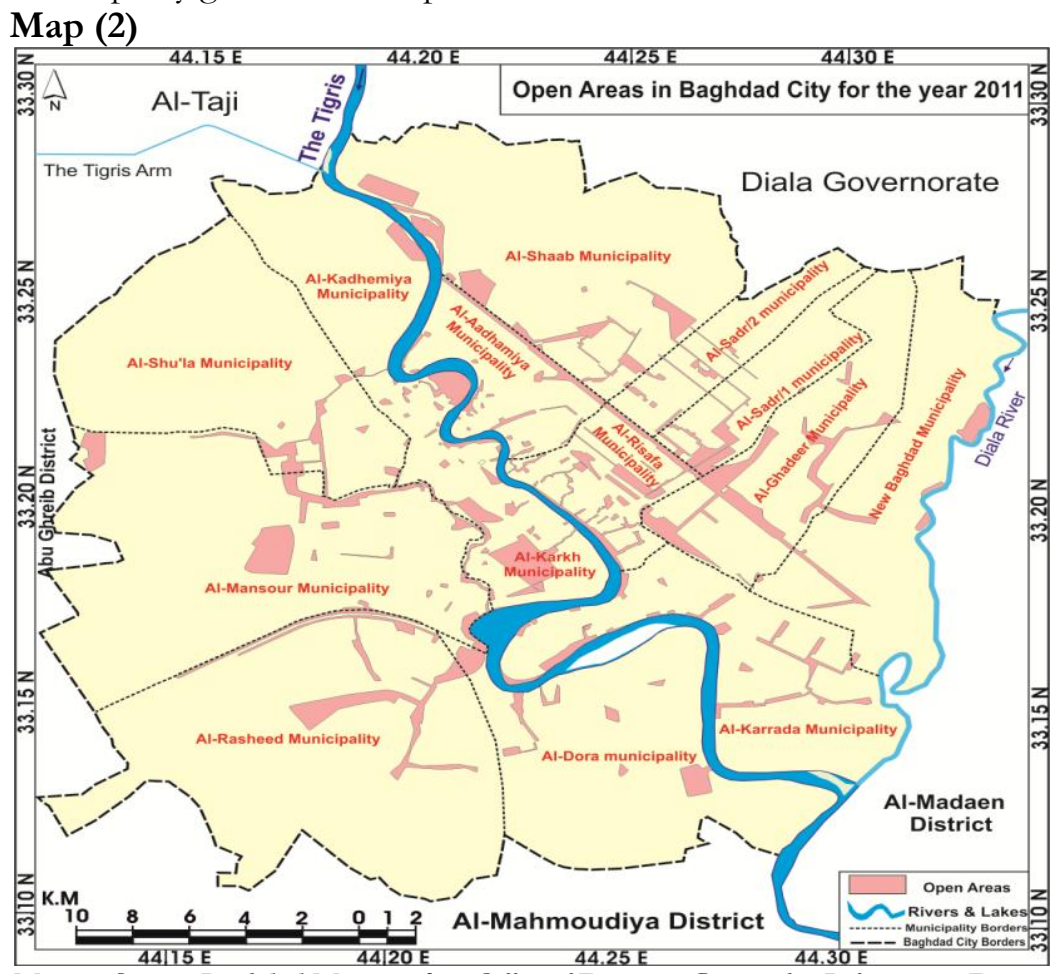

Map 2. Source: Baghdad Municipality, Office of Designs- Geographic Information Dept.

6-A1-Kadhemiya Municipality: This municipality lies north Baghdad city adjacent to the right side of the Tigris which forms two concavities and two convexities as a result of the river meander in a clear way within this municipality. Because its religious function is prominent, it has been a privileged residential area in which there are some parks opposite to the second concavity. As for the agricultural orchards, they are located north of the municipality. The population size of the municipality is estimated about (95228 people) forming a ratio of $(2.8 \%)$ of the overall Baghdad city population, which is a low ratio, yet the area of the open zones within the largest of the populated regions is around $\left(1100540 \mathrm{~m}^{2}\right)\left(32.9 \mathrm{~m}^{2} /\right.$ person), indicating that the open zones represented by orchards has raised the ratio so as to make use of them in spending the weekend holidays.

From the above, it is shown that the green zone within the populated Baghdad city is $\left(13.351 \mathrm{~km}^{2}\right)$, constituting a ratio of the total area of the city $\left(624.13 \mathrm{~km}^{2}\right)$ of about $(2.1 \%)$ of the populated area, which is a small ratio if compared with the population size (3345000 people) for the year (2011), indicating that the planning level, especially for the open zones which are necessary to every city, was not taken into consideration but Baghdad Municipality allowed the space to trespass on them whenever possible, giving 
the city the grey concrete character instead of the green character that provides human with energy, comfort and environmental harmony*.

The necessity of water availability is a must to succeed such projects, as agriculture needs about $(70 \%)$ of available water to be used for agricultural purposes and sustained especially in the hot season. Also, it is required to find outlets in order to have water and to be used for necessary purposes, and not to sprinkle the streets before the houses or washing the cars which should be only in specified places for them for the purpose of limit the waste in water discharge.

\subsection{Fifth- Distribution of Orchards, Nurseries and Agricultural Areas in Baghdad City and Its Green Belt for the Year (2012):}

Baghdad city seems to be grown since its beginning at the expense of planted areas and fertile lands which represent lands immerses with the Tigris water in the seasons of flood annually, because the water of this river was free, i.e. there were no dams built on its springs or at its entrance to Iraq; therefore, the flood were annually adding to the soil a transferred soil that contained organic and mineral materials, so they increased its fertility and renewal continually, thus the agriculture of various kinds flourished. When the development and the need for water emerged whether in the source or outlet States, dams were established, increasing the water shares first and then the sediments carried by the river which remained stuck behind the dams, in that a sort of pure water runs in the river. Also, the population sizes start to increase, especially in the significant cities as in Baghdad city, subsequently the population crawled towards agricultural lands little by little until the urban aspect has dominated the agriculture, except what the State maintained or the population inflation did not yet push to dominate them; therefore, we can note in map (3), that they are distributed in Baghdad city that is really populated and on its green belt in which the human stability did not reach after three agricultural uses of Baghdad city lands*.

1-Orchards: Orchards occupied clear parts inside the populated Baghdad, as the optical map shows their existence in a clear way at the northeastern side, the southwestern side and at south of Baghdad city, constituting in each site an area that differs from each other. The total area of orchards is $\left(86.672 \mathrm{~km}^{2}\right)^{*}$, as the area of orchards at the northeastern part is about $\left(38.3 \mathrm{~km}^{2}\right)$. As for the southwestern part, it occupies $\left(23.1 \mathrm{~km}^{2}\right)$, while the area of orchards at the southern part of Baghdad contains around $\left(18.6 \mathrm{~km}^{2}\right)$, and the orchards located between these parts are sparse beginning from the northwestern until the southeastern, with an area of $\left(6 \mathrm{~km}^{2}\right)$. 


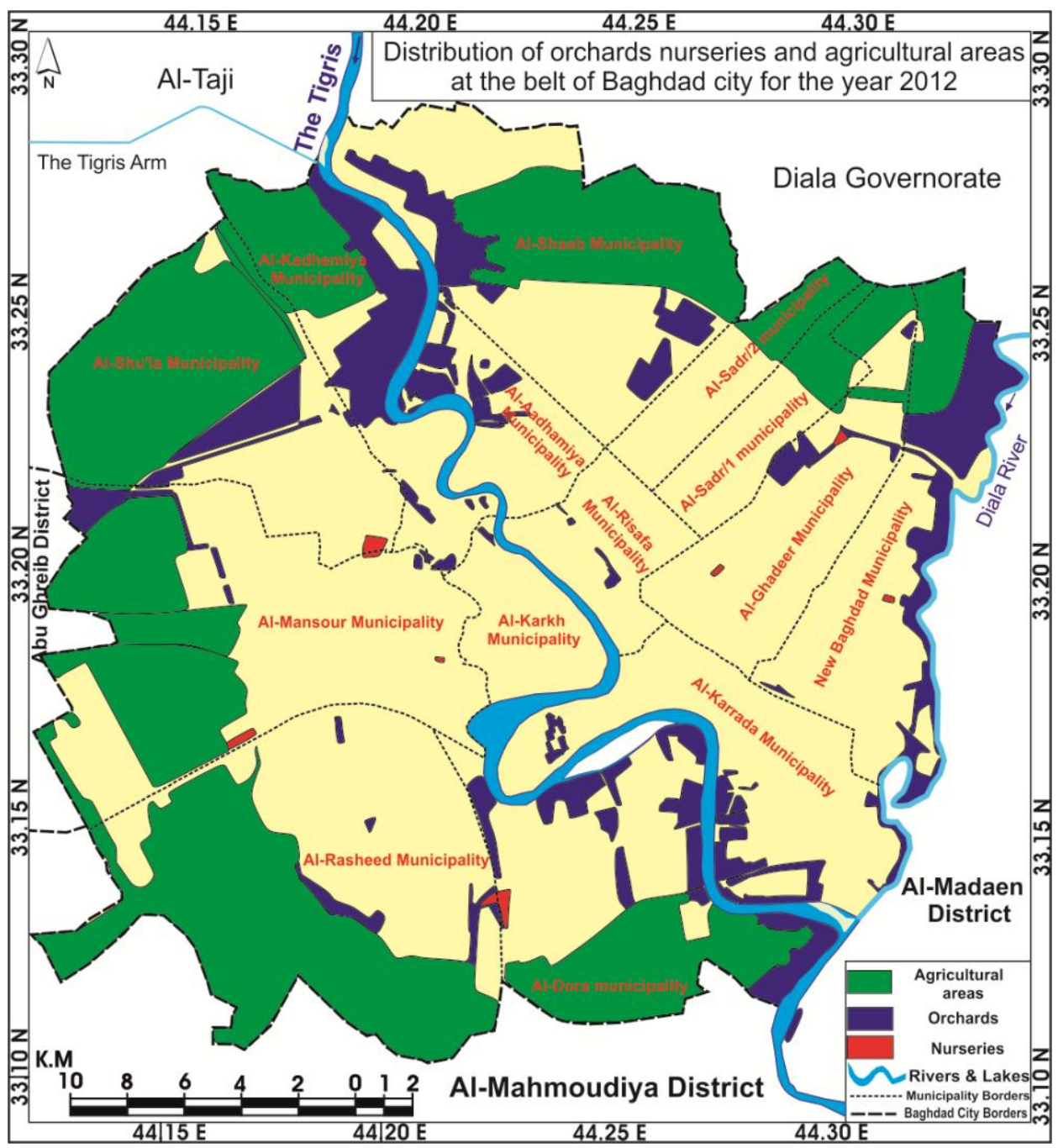

Map 3. Source: Baghdad Municipality, Office of Designs- Geographic Information Dept.

2-Nurseries: Nurseries are distributed inside Baghdad city, surrounded by orchards which are considered as the green belt of Baghdad. They appear at both sides of Baghdad from Al-Risafa and Al-Karkh, occupying an area estimated by $\left(1.712 \mathrm{~km}^{2}\right)$. We can note that $\left(0.787 \mathrm{~km}^{2}\right)$ exists at Al-Risafa side distributed as in map (3), while the area of $\left(0.925 \mathrm{~km}^{2}\right)$ is located at Al-Karkh side in the municipalities of Al-Shu'la, Al-Mansour and Al-Dora. These nurseries supply the houses with internal plants or flowers according to their season so as to plant them in the smalls areas available in the orchards inside the houses, in some governmental offices and institutions or in social clubs distributed in Baghdad city.

3-Agricultural areas: Agricultural areas occupy a large area compared to the previous orchards and nurseries, because Baghdad city represents the capital of Iraq and includes a large population size. It is also of a purchasing capacity that comes at first order 
compared to the rests of Iraq's governorates, i.e. it is a great consumer especially of the necessities that provide a nutrient or recreational domain for Baghdad families. In view of the evident demand on food items, especially the fresh ones, it encouraged the spread of agricultural areas around Baghdad city, which are protected by Baghdad green belt in order to supply the local market with its daily requirements of vegetables to meet the local consuming need of them, as being in a near distance from the local market, making them unexposed to damage because they are quickly damaged by high temperature in the hot season, thus their area is $\left(265.362 \mathrm{~km}^{2}\right)$ which is a very large area surrounding Baghdad city, except the eastern side of it.

\subsection{Sixth- The Green Zones for the Year (2014) in Baghdad City:}

In the year 2014, the map of Baghdad city within the comprehensive developmental plan, map (4) of the land uses in it, indicates that the green zones in general declined evidently more than what they were in 2012 and 2013, thus we find that the orchards became obvious in north and south of Baghdad, especially in the regions surrounding the Tigris, they also disperse at Diala river in the east of the city*.

As for the agricultural areas, after they were surrounding the entire city except the eastern side, they began to interrupt and disperse, especially at the region associated to the road leading to the airport. Also, their area largely decreased in that they lost $\left(67.932 \mathrm{~km}^{2}\right)$, as nothing left from the previous areas but $\left(197.430 \mathrm{~km}^{2}\right)$, and most of which needs a special care after the neglect it suffered from since (2003) until (2009).

The open zones are specially represented by Al-Zawraa Park, Al-Qanat Entertainment City and the opposite side of the University of Baghdad in Al-Jadiriya region which is located at the right bank of the Tigris, all of which are with an area of about $\left(4 \mathrm{~km}^{2}\right)$ and this area if compared to per capita share of the green zones that represent the population's entertaining and recreational domain do not meet the purpose because they are far below the required standard*.

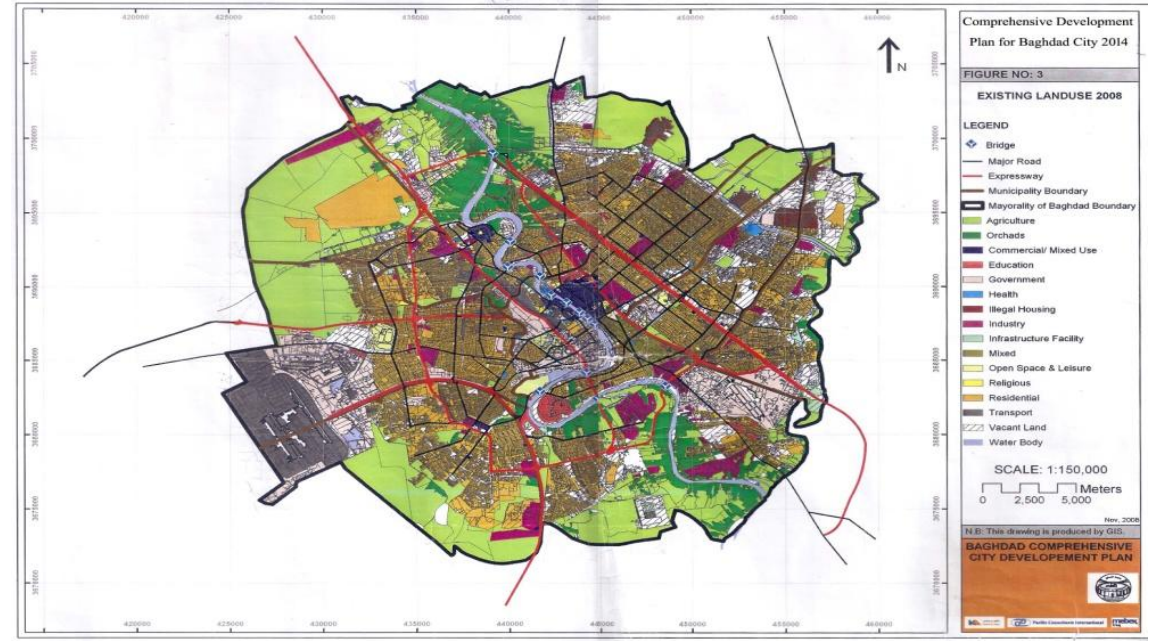

Map 4. Source: Baghdad Municipality, Office of Designs- Geographic Information Dept. 


\subsection{Seventh- The Green Zones in Baghdad City for the Year (2016):}

The green zones inside the city or on its surroundings are necessary to complete the land uses inside the city for they receive a complete interest from the world's States because they reflect the interest of local governments in the city local environment so as to provide the climate suitable for housing, which is reflected on the population ability to achieve as a result of the individual's physical and mental health due to what the governments provide inside the city of means that cast in the interest of human(xii). From this point, we can note map (5) in which the green zones in Baghdad city are represented according to the comprehensive developmental design for the period (2000-2015), as we can notice both agricultural uses as well as the orchards and nurseries which clearly appear at the northern part of the city and along the eastern side by the extension of Diala river in addition to the southern part, they also disperse in some municipalities such as Al-Ghadeer, Al-Shaab, Al-Aadhamiya, Al-Kadhemiya, Al-Shu'la, Al-Mansour, AlKarrada, Al-Rasheed, New Baghdad and Al-Risafa, i.e. they emerge in all municipalities even though in different areas with no consideration to population sizes of each municipality.

The agricultural use also surrounds all sides of Baghdad city except the eastern side adjacent to the Tigris and when moving to land uses in Baghdad city for the year (2016) and afterwards, map (6), we find that the agricultural use began to reduce and the residential neighborhood extensions increased towards the final borders of Baghdad Municipality at the expense of the green belt, as noted in municipalities of Al-Shaab, AlMansour, Al-Rasheed and Al-Dora, too. Also, the municipality of New Baghdad and AlKarrada started to crawl in their both sides towards Diala river until they oversaw the river in some places, which the researcher saw in her field study ${ }^{*}$ in these municipalities, indicating that the green zones are decreasing unless the local governments recognize this crawling in order to preserve the remaining rest, take care of them and maintain them, work at intensifying the efforts and stimulate the concerned actors to work jointly so as to preserve the remaining of these zones, replant them and provide the requirements of their sustainability due to their importance in finding a human characterized with calmness, progress, good taste, and physical and mental health. 


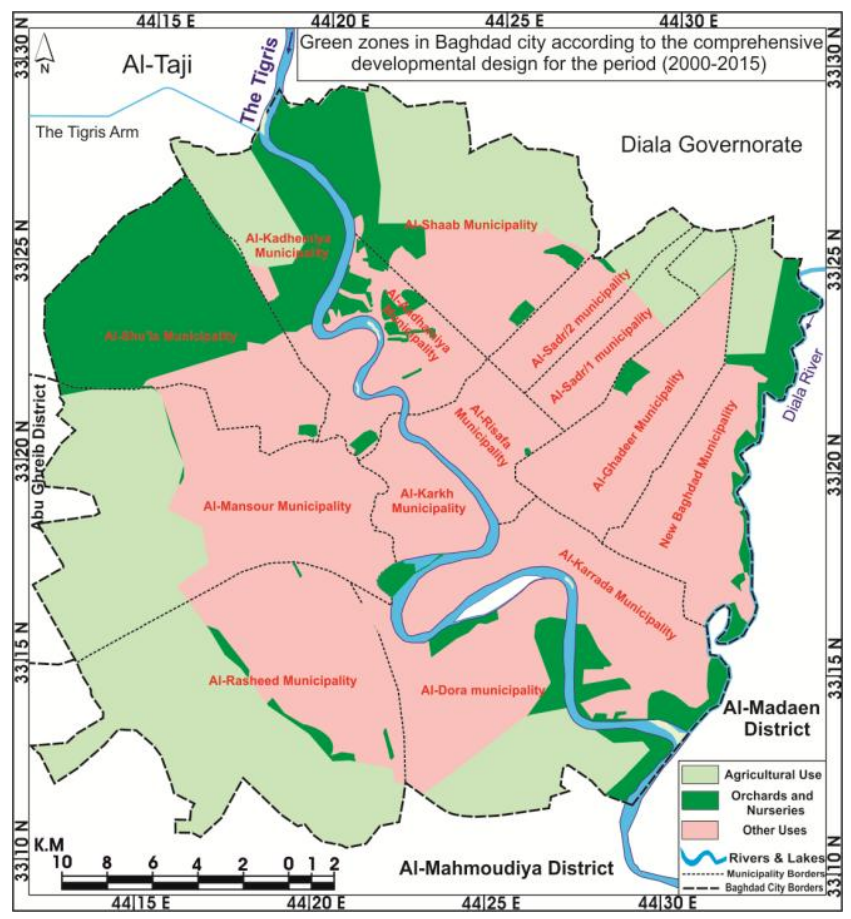

Map 5. Source: Baghdad Municipality, Office of Designs- Geographic Information Dept.

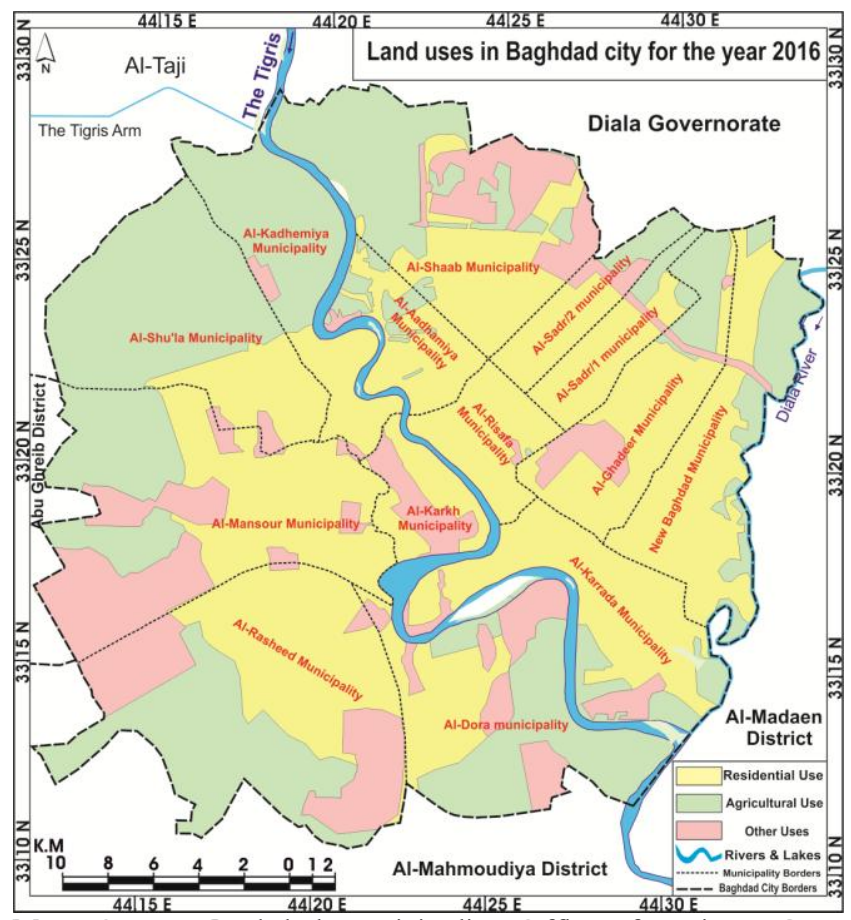

Map 6.Source: Baghdad Municipality, Office of Designs- Geographic Information Dept. 


\section{Conclusions}

1- The per capita share in Baghdad city of the green zones in its whole general and private $\left(0.02 \mathrm{~m}^{2} /\right.$ person), which is very low when compared with the schematic standard associated with the hot regions as in Baghdad city, as they should be $\left(12 \mathrm{~m}^{2} /\right.$ person).

2- The decline of green zones is due to the increase in the population size annually and the increase in demand on the residential supply as well as an increase in the size of small and middle industries at the expense of green lands.

3- The green area within the populated Baghdad city is $\left(13.351 \mathrm{~km}^{2}\right)$, constituting a percentage of the total area of the city which is $\left(624.13 \mathrm{~km}^{2}\right)$ of about $(2.1 \%)$ of the populated area, and this is a small percentage if compared with the population size (3345000 people) for the year 2011.

4- There are three agricultural uses distributed in the already populated Baghdad city and on its green belt which has not yet reached a high population density: the orchards with a total area $\left(86.672 \mathrm{~km}^{2}\right)$, nurseries with a total area $\left(1.712 \mathrm{~km}^{2}\right)$, and the agricultural areas with a total area $\left(265.362 \mathrm{~km}^{2}\right)$.

5- The year (2014) indicates a decline of land uses of green zones in Baghdad city, as the area of agricultural areas largely decreased in that they lost $\left(67.932 \mathrm{~km}^{2}\right)$, where nothing left but $\left(430 \mathrm{~km}^{2}\right)$. As for the open regions, their area is about $\left(4 \mathrm{~km}^{2}\right)$, and this area if compared with the per capita share of the green zones that represent the population's recreational aspect does not meet the purpose because it is far below the required standard.

6- As for the land uses in Baghdad city for the year (2016), we find that the agricultural use started to reduce and the extensions of residential neighborhoods increase towards the final borders of Baghdad Municipality at the expense of the green belt.

7- The green areas in Baghdad city for the year (2016) started to decrease, as the local government did not recognize this crawling so as to preserve the remaining rest, take care of them, maintain them, replant them, and provide the requirements of their sustainability due to their importance in finding a human characterized with calmness, elegance, good taste and physical and mental health.

\section{Appendix (1)}

First: Al-Risafa municipality

\begin{tabular}{|l|l|l|l|l|l|}
\hline No. & Residential neighborhood & Population Estimates for 2016 & Areas $\mathbf{~ m}^{\mathbf{2}}$ & Densities & $\mathbf{\%}$ \\
\hline 1. & Al-Mustansiriya & 37857 & 7.65 & 5666 & 0.46 \\
\hline 2. & Al-Idrisi & 23468 & 2.01 & 14409 & 1.20 \\
\hline 3. & Al-Neel & 10635 & 2.86 & 5640 & 0.426 \\
\hline 4. & Al-Gailani & 4427 & 2.03 & 4887 & 0.45 \\
\hline 5. & Al-Jimhouriya & 40557 & 1.10 & 46859 & 3.91 \\
\hline 6. & Al-Nidhal & 5676 & 1.88 & 5941 & 0.49 \\
\hline 7. & Al-Saadoun & 12324 & 1.30 & 17932 & 1.51 \\
\hline 8. & Abu Nu'as & 3952 & 1.26 & 3136 & 0.26 \\
\hline 9. & Al-Rasheed & 8577 & 2.08 & 6765 & 0.56 \\
\hline 10. & Al-Sheikh Omer & 4025 & 2.16 & 3135 & 0.25 \\
\hline 11. & Al-Uloum & 274 & 1.00 & 274 & 0.02 \\
\hline 12. & Al-Tib & 3529 & 1.25 & 5021 & 0.41 \\
\hline 13. & 14 July & 18297 & 2.20 & 13311 & 1.11 \\
\hline & Total & 173598 & 28.78 & 132976 & 11.07 \\
\hline
\end{tabular}


Second: Al-Karrada municipality

\begin{tabular}{|l|l|l|l|l|l|}
\hline No. & Residential neighborhood & $\begin{array}{l}\text { Population } \\
\text { Estimates for } \mathbf{2 0 1 6}\end{array}$ & Areas $\mathbf{K m}^{\mathbf{2}}$ & Densities & $\mathbf{\%}$ \\
\hline 1. & Al-Jamiaa & 17457 & 9.19 & 2555 & \\
\hline 2. & Babel & 29712 & 8.20 & 3148 & \\
\hline 3. & Al-Karrada & 41852 & 3.90 & 17424 & \\
\hline 4. & Al-Riyadh & 16184 & 2.20 & 9629 & 0.80 \\
\hline 5. & Al-Wihda & 21274 & 3.72 & 8702 & 0.72 \\
\hline 6. & Al-Sindbad & 5266 & 6.30 & 1010 & 0.07 \\
\hline 7. & Al-Zaafaraniya & 31617 & 13.83 & 3956 & 0.32 \\
\hline 8. & Diala & 51057 & 9.80 & 11774 & 1.00 \\
\hline & Total & 214419 & 57.14 & 58198 & 2.917 \\
\hline
\end{tabular}

Third: Al-Aadhamiya municipality

\begin{tabular}{|l|l|l|l|l|l|}
\hline No. & Residential neighborhood & $\begin{array}{l}\text { Population } \\
\text { Estimates for 2016 }\end{array}$ & Areas $\mathbf{K m}^{\mathbf{2}}$ & Densities & $\mathbf{\%}$ \\
\hline 1. & Tunis & 13303 & 2.94 & 12640 & 1.09 \\
\hline 2. & Al-Shamasiya & 65579 & 4.40 & 20315 & 1.71 \\
\hline 3. & Al-Maghrib & 14423 & 3.1 & 12333 & 1.02 \\
\hline 4. & Al-Waziriya & 12208 & 2.6 & 4695 & 0.38 \\
\hline 5. & Al-Qahira & 37788 & 3.10 & 19870 & 1.65 \\
\hline 6. & Al-Rabee' & 42993 & 8.53 & 7831 & 0.65 \\
\hline 7. & Al-Aadhamiya & 38166 & 2.0 & 30988 & 2.60 \\
\hline & Total & 224460 & 26.67 & 108672 & 9.1 \\
\hline
\end{tabular}

Fourth: New Baghdad municipality

\begin{tabular}{|l|l|l|l|l|l|}
\hline No. & Residential neighborhood & $\begin{array}{l}\text { Population } \\
\text { Estimates for 2016 }\end{array}$ & Areas $\mathbf{K m}^{\mathbf{2}}$ & Densities & $\mathbf{\%}$ \\
\hline 1. & Al-Khaleej Al-Arabi & 151823 & 12.68 & 114790 & 1.23 \\
\hline 2. & Al-Ameen & 259708 & 14.73 & 120056 & 1.67 \\
\hline 3. & Al-Khansaa & 83624 & 9.93 & 12.54 & 1.05 \\
\hline 4. & Al-Maamoun & 101142 & 15.40 & 8887 & 0.76 \\
\hline & Total & 596297 & 52.74 & 243745.54 & 4.71 \\
\hline
\end{tabular}

Fifth: Al-Ghadeer (9 Nissan) municipality

\begin{tabular}{|l|l|l|l|l|l|}
\hline No. & Residential neighborhood & $\begin{array}{l}\text { Population } \\
\text { Estimates for 2016 }\end{array}$ & Areas $\mathbf{~ m}^{\mathbf{2}}$ & Densities & $\mathbf{\%}$ \\
\hline 1. & Al-Muthanna & 38874 & 688 & 12069 & 1.01 \\
\hline 2. & Sumer $/ 1$ & 30270 & 3.12 & 21148 & 1.76 \\
\hline 3. & 9 Nissan & 24269 & 7.34 & 8172 & 0.68 \\
\hline 4. & Akad & 134441 & 21.38 & 7959 & 0.66 \\
\hline 5. & Al-Mu'tasim & 253 & 3.00 & 84 & 0.00 \\
\hline & Total & 228107 & 41.02 & 49432 & 4.11 \\
\hline
\end{tabular}

Sixth: Al-Sadr/1 municipality

\begin{tabular}{|l|l|l|l|l|l|}
\hline No. & Residential neighborhood & $\begin{array}{l}\text { Population } \\
\text { Estimates for 2016 }\end{array}$ & Areas $\mathbf{~ K m}^{\mathbf{2}}$ & Densities & $\mathbf{\%}$ \\
\hline 1. & Al-Sadr/1 City & 530322 & 18.67 & 38295 & 3.20 \\
\hline 2. & Ishbilia & 141278 & 4.55 & 37557 & 3.15 \\
\hline & Total & 671600 & 23.22 & 75852 & 6.35 \\
\hline
\end{tabular}

Seventh: Al-Sadr/2 municipality

\begin{tabular}{|l|l|l|l|l|l|}
\hline No. & Residential neighborhood & $\begin{array}{l}\text { Population } \\
\text { Estimates for 2016 }\end{array}$ & Areas $\mathbf{~ m}^{\mathbf{2}}$ & Densities & $\mathbf{\%}$ \\
\hline 1. & Al-Sadr/2 City & 429867 & 10.53 & 59475 & 5.00 \\
\hline 2. & Jamila & 38749 & 3.90 & 14514 & 1.20 \\
\hline & Total & 468616 & 14.43 & 73989 & 6.20 \\
\hline
\end{tabular}

Eighth: Al-Shaab municipality

\begin{tabular}{|l|l|l|l|l|l|}
\hline No. & Residential neighborhood & $\begin{array}{l}\text { Population } \\
\text { Estimates for 2016 }\end{array}$ & Areas $\mathbf{K m}^{\mathbf{2}}$ & Densities & $\mathbf{\%}$ \\
\hline 1. & Al-Shaab & 71870 & 3.40 & 26313 & 2.20 \\
\hline 2. & Al-Baidhaa & 43771 & 4.00 & 15407 & 1.29 \\
\hline
\end{tabular}




\begin{tabular}{|l|l|l|l|l|l|}
\hline 3. & Sumer/2 & 8828 & 1.30 & 20527 & 1.72 \\
\hline 4. & Al-Tujjar & 8282 & 1.70 & 20107 & 1.68 \\
\hline 5. & Adan & 70208 & 1.30 & 67742 & 0.56 \\
\hline 6. & Al-Basateen & 10711 & 7.30 & 1467 & 0.11 \\
\hline 7. & Ur & 71880 & 5.10 & 17595 & 1.47 \\
\hline 8. & Al-Mehdi & 75447 & 32.17 & 2900 & 0.23 \\
\hline 9. & Al-Fahhama (Gmeira) & 11518 & 33.60 & 343 & 0.01 \\
\hline 10. & Um Al-Kibar wal Gizlan & 4031 & 3.72 & 5884 & 0.49 \\
\hline 11. & Sabi' Al-Bour & 5322 & 6.45 & 825 & 0.00 \\
\hline
\end{tabular}

Total of Risafa Side

4163235

349.1

11925

56.12

Municipalities of Karkh Side

First: Al-Karkh municipality

\begin{tabular}{|l|l|l|l|l|l|}
\hline No. & Residential neighborhood & $\begin{array}{l}\text { Population } \\
\text { Estimates for 2016 }\end{array}$ & Areas $\mathbf{K m}^{\mathbf{2}}$ & Densities & \% \\
\hline 1. & Al-Salihiya & 8352 & 2.31 & 11346 & 0.94 \\
\hline 2. & Al-Zawraa & 28 & 2.68 & 10 & 0.00 \\
\hline 3. & Al-Tashri' & 3016 & 4.78 & 631 & 0.04 \\
\hline 4. & Al-Sheikh Jneid & 3749 & 3.84 & 976 & 0.07 \\
\hline 5. & Al-Kindi & 3360 & 3.01 & 7049 & 0.59 \\
\hline 6. & Al-Jana'in & 243 & 1.72 & 141 & 0.01 \\
\hline 7. & Al-Karkh & 6181 & 1.30 & 18491 & 1.54 \\
\hline 8. & Al-Sheikh Ma'rouf & 73192 & 4.20 & 21678 & 1.82 \\
\hline & Total & 71429 & 23.84 & 60.322 & 5.01 \\
\hline
\end{tabular}

Second: Al-Dora municipality

\begin{tabular}{|l|l|l|l|l|l|}
\hline No. & Residential neighborhood & $\begin{array}{l}\text { Population } \\
\text { Estimates for 2016 }\end{array}$ & Areas $\mathbf{K m}^{\mathbf{2}}$ & Densities & $\mathbf{\%}$ \\
\hline 1. & Al-Khawarnaq & 24119 & 19.56 & 2116 & 0.17 \\
\hline 2. & Zubaida & 172548 & 8.86 & 16896 & 1.41 \\
\hline 3. & Al-Jaza'ir & 17406 & 1.64 & 19934 & 1.66 \\
\hline 4. & Al-Hadhr (Al-Dora) & 111373 & 6.81 & 23528 & 1.97 \\
\hline 5. & Al-Jazeera & 9106 & 9.0 & 2599 & 0.21 \\
\hline & Total & 334.552 & 54.87 & 65073 & 5.42 \\
\hline
\end{tabular}

Third: Al-Shu'la municipality

\begin{tabular}{|l|l|l|l|l|l|}
\hline No. & Residential neighborhood & $\begin{array}{l}\text { Population } \\
\text { Estimates for 2016 }\end{array}$ & Areas $\mathbf{K m}^{\mathbf{2}}$ & Densities & $\mathbf{\%}$ \\
\hline 1. & Al-Shu'la (Nour) & 168365 & 21.1 & 13057 & 1.09 \\
\hline 2. & Al-Harbiya & 15262 & 4.48 & 3407 & 0.28 \\
\hline 3. & Al-Huriya & 2250618 & 9.87 & 33726 & 2.82 \\
\hline 4. & Al-Abbasiya & 285 & 2.52 & 113 & 0.01 \\
\hline & Total & 409.530 & 37.97 & 50303 & 4.2 \\
\hline
\end{tabular}

Fourth: Al-Rasheed municipality

\begin{tabular}{|l|l|l|l|l|l|}
\hline No. & Residential neighborhood & $\begin{array}{l}\text { Population } \\
\text { Estimates for 2016 }\end{array}$ & Areas $\mathbf{K m}^{\mathbf{2}}$ & Densities & \% \\
\hline 1. & Al-Warkaa (Al-Aamel) & 168615 & 6.84 & 27105 & 2.26 \\
\hline 2. & Al-Jihad & 83650 & 8.33 & 13257 & 1.11 \\
\hline 3. & Badr (Al-Furat) & 27124 & 3.74 & 7252 & 0.60 \\
\hline 4. & Al-Ta'meem & 106152 & 5.83 & 22802 & 1.91 \\
\hline 5. & Thi Qar & 26526 & 3.96 & 13462 & 1.12 \\
\hline 6. & Al-Ma'rifa & 25124 & 2.90 & 17899 & 1.50 \\
\hline 7. & Al-Buwaib & 12310 & 12.28 & 1002 & 0.07 \\
\hline 8. & Ajnadeen & 115613 & 14.83 & 10276 & 0.86 \\
\hline 9. & Maisaloun & 54248 & 3.02 & 26831 & 2.25 \\
\hline 10. & Tabouk & 31329 & 6.15 & 9449 & 0.79 \\
\hline
\end{tabular}

Fifth: Al-Mansour municipality

\begin{tabular}{|l|l|}
\hline No. & Residential neighborhood \\
\hline
\end{tabular}

Population

Areas $\mathbf{K m}^{2}$

Densities

$\%$ 


\begin{tabular}{|l|l|l|l|l|l|}
\hline & & $\begin{array}{l}\text { Estimates for } \\
\mathbf{2 0 1 6}\end{array}$ & & & \\
\hline 1. & Jneina & 4689 & 4.17 & 963 & 0.07 \\
\hline 2. & Al-Ghazaliya & 128721 & 16.28 & 8784 & 0.73 \\
\hline 3. & Al-Adl & 2013 & 6.13 & 5610 & 0.46 \\
\hline 4. & Al-Khadhraa & 77028 & 8.19 & 11149 & 0.93 \\
\hline 5. & Ramadhan & 61687 & 1.92 & 39569 & 3.3 \\
\hline 6. & Al-Mutanabi & 14794 & 2.86 & 5173 & 0.43 \\
\hline 7. & Al-Mansour & 13077 & 2.54 & 10772 & 0.90 \\
\hline 8. & Al-Andulus & 25171 & 2.87 & 13748 & 1.15 \\
\hline 9. & Al-Qadisiya & 9130 & 3.88 & 6035 & 0.50 \\
\hline 10. & Al-Yarmouk & 16584 & 4.40 & 7000 & 0.58 \\
\hline 11. & Hitteen (Al-Hamraa) & 8724 & 3.92 & 5870 & 0.48 \\
\hline 12. & Al-Aamiriya (Al-Firdos) & 66680 & 6.40 & 12652 & 1.0 \\
\hline & Total & 446388 & 64.40 & 127325 & 10.54 \\
\hline
\end{tabular}

Sixth: Al-Kadhemiya municipality

\begin{tabular}{|l|l|l|l|l|l|}
\hline No. & Residential neighborhood & $\begin{array}{l}\text { Population } \\
\text { Estimates for } \\
\mathbf{2 0 1 6}\end{array}$ & Areas $\mathbf{K m}^{\mathbf{2}}$ & Densities & \% \\
\hline 1. & Al-Taji & 1120 & 9.79 & 114 & 0.01 \\
\hline 2. & Al-Kadhemiya & 36307 & 5.10 & 11788 & 1.0 \\
\hline 3. & Al-Zahraa & 32166 & 3.73 & 15007 & 1.25 \\
\hline 4. & Al-Uteifiya & 25854 & 1.82 & 14205 & 1.19 \\
\hline 5. & Al-Fajr & 12624 & 2.30 & 5489 & 0.45 \\
\hline 6. & Al-Salam & 34771 & 3.33 & 17592 & 1.46 \\
\hline & Total & 142842 & 26.07 & 64.195 & 5.35 \\
\hline
\end{tabular}

Source: Baghdad Municipality, Office of Designs- GIS Dept., Unpublished Data.

\section{References}

1. Abdul Razzaq Abbas Hussein, The Geography of Cities, Asaad Printing House, Baghdad, 1977.

2. Baghdad Municipality, Office of Designs, Department of Geographic Information Systems, Map of the use of open areas of Baghdad City, 2006.

3. Baghdad Municipality, Office of Designs, Department of Geographic Information Systems, Unpublished Data, 2012.

4. Jabra Ibrahim Jabra and Dr. Ihsan Fathi, Baghdad between Yesterday and Today, Municipality of Baghdad, Department of Urban Planning, 1989.

5. London W., Cities and Spaces, The Future Use of Urban Lands, McGraw Hill, 1963.

6. Ministry of Planning, Central Organ of Population Statistics, Estimates of 2010, Unpublished

Data.

7. Ministry of Planning, Central Organ of Statistics, Department of Information Systems, Unpublished Data, 2016.

8. Ministry of Planning, Central Organ of Statistics, Department of Geographic Information, Estimates of Populations for 2011, Unpublished Data.

9. Mohammed Abdul Rahman Mohammed Al-Bdeiri, The Sustainability of Green Spaces in Baghdad City, PhD Thesis, College of Engineering, University of Baghdad, 2013.

10. Mohammed Fadhel Ismael, Planning the Open Spaces inside the Cities, A Master Thesis, Center of Urban and Regional Planning, University of Baghdad, 1960.

11. Rubenstein, A Guide to Site and Environmental Planning, 1980.

12. Xin Min, Green Open Space in Shanghai, Ministry of Trade, China, 2011.

\section{Endnotes and References}

(i) Xin Min, Green Open Space in Shanghai, Ministry of Trade, China, 2011, P.248. 
(ii) Abdul Razzaq Abbas Hussein, The Geography of Cities, Asaad Printing House, Baghdad, 1977, P.154.

(iii) London W., Cities and Spaces, The Future Use of Urban Lands, McGraw Hill, 1963, P.77.

(iv) Xin Min, Green Open Space in Shanghai, Op.Cit, P.247.

(v) Jabra Ibrahim Jabra and Dr, Ihsan Fathi, Baghdad between Yesterday and Today, Municipality of Baghdad, Department of Urban Planning, 1989, P.117.

"The Field Study, Wednesday 13-2-2016, 10:00 am.

(vi) Ministry of Planning, Central Organ of Statistics, Department of Information Systems, Unpublished Data, 2016.

(vii) Baghdad Municipality, Office of Designs, Department of Geographic Information Systems, Map of the use of open areas of Baghdad City, 2006.

(viii) Ministry of Planning, Central Organ of Population Statistics, Estimates of 2010, Unpublished Data.

(ix) Mohammed Abdul Rahman Mohammed Al-Bdeiri, The Sustainability of Green Spaces in Baghdad City, PhD Thesis, College of Engineering, University of Baghdad, 2013, P.158.

"Field Study, Wednesday 19/10/2016, 11:30 am.

"Field Study, Sunday 15-5-2016, 11:00 am.

(x) Rubenstein, A Guide to Site and Environmental Planning, 1980, P.51.

"All the ratios $\left(\mathrm{m}^{2} /\right.$ person) were extracted by the researcher.

(xi) Ministry of Planning, Central Organ of Statistics, Department of Geographic Information, Estimates of Populations for 2011, Unpublished Data.

"Field Study, Tuesday 22/11/2011, 9:00 am.

"Field Study, Thursday 18/10/2012, 10:00 am

"All the numbers cited in these items were adopted according to the GIS in Baghdad Municipality, Office of Designs, Department of Geographic Information Systems, Unpublished Data, 2012.

"Field Study, Sunday 22-12-2013, 9:00 am.

"Field Study, Tuesday 25-11-2014, 12:00 am.

(xii) Mohammed Fadhel Ismael, Planning the Open Spaces inside the Cities, A Master Thesis, Center of Urban and Regional Planning, University of Baghdad, 1960, P.6.

"Field Study, Monday 26/9/2016, 10:00 am.

"There are two neighborhoods in the same name in the municipalities of Al-Ghadeer and Al-Shaab. 